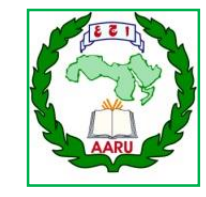

Arab Univ. J. Agric. Sci., Ain Shams Univ., Cairo, Egypt

29(2), 787-793, 2021

Website: http://ajs.journals.ekb.eg

DOI: 10.21608/ajs.2021.82532.1397

787

\title{
Foliar Fertilization of Different Species of Mulberry Trees and Its Impact on Silk worm Bombyx mori Productivity from Cocoons and Eggs
}

\author{
Sawsan M Abdelmegeed* \\ Plant Protection Dept, Fac of Agric, Ain Shams Univ, P.O. Box 68, Hadayek \\ Shoubra 11241, Cairo, Egypt \\ * Corresponding author: sawsan_ali@agr.asu.edu.eg
}

Received 3 July, 2021

Accepted7 August, 2021

\begin{abstract}
Rearing mulberry silkworm was found to be dependent on leaves quality of mulberry trees, larvae of mulberry silkworm fed on two species of mulberry trees Morus alba and Morus nigra were treated with foliar fertilizer (Basfoliar 20-19-19 SP contains 20\% N, 19\% $\mathrm{P}_{2} \mathrm{O}_{5}, 19 \% \quad \mathrm{~K}_{2} \mathrm{O}, 5 \% \mathrm{NO}_{3}, 3.6 \% \mathrm{NH}_{4}$ and $11.4 \% \mathrm{NH}_{2}$ ) with three different concentrations, $1 \%, 3 \%$ and $6 \%$ in addition to control treatment for comparison. When larvae were fed on leaves of mulberry trees one day after Treatment, high mortality (up to $100 \%$ ) was observed specially with $6 \%$ concentration. Mean weights of larvae, cocoons and cocoon shell and fecundity were negatively affected when compared to control. On the other hand, when larvae were fed on leaves of mulberry trees, no mortality occurred after two weeks of treatment in all concentrations, in addition, the mean weights of larvae at the end of $4^{\text {th }}$ and $5^{\text {th }}$ instar larvae, cocoons and cocoon shell s increased at $3 \%$ concentration compared with other concentrations and control. The highest fecundity occurred in female moths when larvae were fed on leaves of $M$.nigra compared with $M$. alba as well as $3 \%$ concentration compared with other concentrations and control.
\end{abstract}

Keywords: Foliar fertilization, Mulberry trees, Mulberry silkworm, Morus alba, Morus nigra, Bombyx mori

\section{Introduction}

Mulberry trees were cultivated in Egypt for the purpose of rearing mulberry silkworms for more than 200 years, and they were grown on the edges of canals, and farmers did not care to prune them (Pawan et al 2017) or control the pests that afflicted them (Shinde et al 2012, Łochyńska 2018) or even fertilize them (Mahmood et al 2001, Radi et al 2003, Shal et al 2003,József et al 2005, Asma et al 2007, Dhillon et al 2011, El-Khayat et al 2013, Kamel2014, Sugiyamaet al 2016) or take care of them, which led to the deterioration of the mulberry trees and the nutritional value of them became low, which Negatively affected silk production in terms of quantity and quality. Taking care of mulberry trees by introducing new types and varieties (Abdelmegeed 2016), improved nutrition value of leaves via food additions (Salman et al 2011, Abdelmegeed 2020), attention to pruning (Pawan et al 2017), cultivation distances (Shinde et al 2012, Łochyńska 2018), pest control (Sakthivel et al 2019), fertilization (Sugiyama et al 2016) and irrigation (Sudhakar et al 2018) has increased both quantity and quality of leaves. 
The aim of the study is to follow up the effect of fertilizing mulberry trees with different concentrations of a foliar fertilizer and its effects on weight of mulberry silkworm larvae, production of cocoons, silk production, as well as the fecundity and fertility of eggs.

\section{Materials and Methods}

All laboratory and field experiments were conducted at the Plant Protection Department, Fac. Agric., Ain Shams Univ., Cairo, Egypt. Larvae of mulberry silkworm were reared from eggs obtained from the Sericulture Research Unit, Agric. Res. Center, MoA, Giza, Egypt, and rearing was carried out under appropriate breeding conditions in the laboratory during the spring season according to Krishanaswami (1983).

\subsection{Mulberry trees treated with foliar ferti- lization}

Two species of mulberry trees were selected for foliar fertilization treatment Morus alba and Morus nigra. Different concentrations ( $1 \mathrm{gm} / \mathrm{liter}, 3 \mathrm{gm} / \mathrm{liter}$ and $6 \mathrm{gm} / \mathrm{liter})$ from the foliar fertilizer Basfoliar 20-19-19SPContains $20 \% \mathrm{~N}, 19 \% \mathrm{P}_{2} \mathrm{O}_{5}, 19 \% \mathrm{~K}_{2} \mathrm{O}, 5 \% \mathrm{NO}_{3}$, $3.6 \% \mathrm{NH}_{4}$ and $11.4 \% \mathrm{NH}_{2}$ were prepared. Mulberry trees were sprayed early in the moming before sun rise weekly for four times in a row and 24 trees of mulberry trees were select (12 trees of M. alba and 12 trees of M. nigra) and treated with the different concentrations of fertilizer, each concentration for three trees.

\subsection{Mulberry silkworm rearing}

Newly hatched larvae of mulberry silkworm were divided in to two groups, each one consisted of 120 larvae fed on leaves treated with different concentrations $(1 \%, 3 \%, 6 \%$ and control) of the fertilizer. The first group fed on treated leaves after one day of spraying with the fertilizer, and larvae of the second group were fed on treated leaves after two weeks of treatment.
Mortality percentages were calculated by the end of each larval instar, larvae in the end of $4^{\text {th }}$ and $5^{\text {th }}$ instars were weighted, weighted the cocoons and cocoon shells were also weighted, and fecundity after mating of moths and the eggs being laid was estimated.

\section{Results and Discussions}

\subsection{Mortality}

Mortality of larvae was affected by different concentration of foliar fertilization when the larvae were fed on leaves after one day of treatment. On the other hand, no mortality occurred in the larvae when were fed on leaves after 2 weeks of treatment. The highest mortality $(100 \%)$ occurred at $6 \%$ concentration when $2^{\text {nd }}$ instar larvae were fed on leaves of M. alba. The highest mortality increased in $1^{\text {st }}$ and $2^{\text {nd }}$ instar larvae while it decreased in $3^{\text {rd }}$ and $4^{\text {th }}$ instar larvae until it reached zero in $5^{\text {th }}$ instar larvae. Table 1.

\subsection{Mean weights of larvae}

Mean weights of larvae were negatively affected by feeding on leaves treated with different concentrationsfor the foliar fertilizer. After one day of treatment, mean weights of the larvae decreased at the end of the $4^{\text {th }}$ and $5^{\text {th }}$ instars with an increase in the concentration compared to the control. Table 2

On the other hand, mean weights of larvae at the end of $4^{\text {th }}$ and $5^{\text {th }}$ instars increased significantly at concentration $3 \%$ when compared with $1 \%$ and $6 \%$ and control Table 3.

\subsection{Mean weights of cocoons and cocoon shells}

Mean weights of cocoons and cocoon shells were affected by different concentrations of foliar fertilization when larvae of mulberry silkworm were fed on leaves of mulberry trees treated with foliar fertilization. 


\section{Foliar Fertilization of Different Species of Mulberry Trees and Its Impact}

on Silkworm Bombyx mori Productivity from Cocoons and Eggs

Table 1. Mortality of larvae fed on mulberry leaves treated with foliar fertilization one day after treatment

\begin{tabular}{|c|c|c|c|c|c|c|c|c|c|c|}
\hline \multirow{2}{*}{ Conc } & \multicolumn{2}{|c|}{$1^{\text {st }}$ instar larvae } & \multicolumn{2}{|c|}{$2^{\text {nd }}$ instar larvae } & \multicolumn{2}{|c|}{$3^{\text {rd }}$ instar larvae } & \multicolumn{2}{|c|}{$4^{\text {th }}$ instar larvae } & \multicolumn{2}{|c|}{$5^{\text {th }}$ instar larvae } \\
\hline & M. alba & M. nigra & M. alba & M. nigra & M. alba & M. nigra & M. alba & M. nigra & M. alba & M. nigra \\
\hline 1 & 20 & 10 & 30 & 15 & 10 & 10 & 5 & 5 & 0 & 0 \\
\hline 3 & 40 & 30 & 60 & 40 & 20 & 20 & 15 & 7 & 0 & 0 \\
\hline 6 & 80 & 50 & 100 & 60 & 100 & 30 & 100 & 5 & 100 & 0 \\
\hline cont & 0 & 0 & 0 & 0 & 0 & 0 & 0 & 0 & 0 & 0 \\
\hline
\end{tabular}

Table 2. Weights of larvae in the end of the $4^{\text {th }}$ and $5^{\text {th }}$ instar larvae fed on mulberry leaves treated with foliar fertilization one day after treatment

\begin{tabular}{|c|c|c|c|c|}
\hline \multirow{2}{*}{ Conc (gm/liter) } & \multicolumn{2}{|c|}{ W. $4^{\text {th }}$ instar larvae } & \multicolumn{2}{|c|}{ W. $5^{\text {th }}$ instar larvae } \\
\hline & M. alba & M. nigra & M. alba & M. nigra \\
\hline 1 & $0.6145^{\mathrm{a}} \pm 0.0089$ & $0.7457^{\mathrm{a}} \pm 0.0095$ & $3.5163^{\mathrm{b}} \pm 0.056$ & $3.6223^{\mathrm{a}} \pm 0.0461$ \\
\hline 3 & $0.6012^{\mathrm{a}} \pm 0.0078$ & $0.6875^{\mathrm{b}} \pm 0.0097$ & $3.1146^{\mathrm{c}} \pm 0.0732$ & $3.2664^{\mathrm{b}} \pm 0.0982$ \\
\hline 6 & $0.00^{\mathrm{b}} \pm 0.00$ & $0.5539^{c} \pm 0.0146$ & $0.00^{\mathrm{d}} \pm 0.00$ & $2.9597^{\mathrm{c}} \pm 0.0393$ \\
\hline Cont & $0.6128^{a} \pm 0.0051$ & $0.6532^{\mathrm{b}} \pm 0.0154$ & $3.7946^{\mathrm{a}} \pm 0.0438$ & $3.471^{\mathrm{a}} \pm 0.0327$ \\
\hline F. Value & $4444.87 * *$ & $81.37 * *$ & $2372.40 * *$ & $45.69 * *$ \\
\hline L.S.D. & 0.0207 & 0.0404 & 0.1636 & 0.1921 \\
\hline
\end{tabular}

Table 3. Weights of larvae in the end of the $4^{\text {th }}$ and $5^{\text {th }}$ instar larvae fed on mulberry leaves treated with foliar fertilization two weeks after treatment

\begin{tabular}{|c|c|c|c|c|}
\hline \multirow{2}{*}{ Conc (gm/liter) } & \multicolumn{2}{|c|}{ W. $4^{\text {th }}$ instar larvae } & \multicolumn{2}{|c|}{ W. $5^{\text {th }}$ instar larvae } \\
\hline & M. alba & M. nigra & M. alba & M. nigra \\
\hline 1 & $0.6123^{\mathrm{b}} \pm 0.0054$ & $0.6636^{\mathrm{b}} \pm 0.0062$ & $3.7081^{\mathrm{b}} \pm 0.0279$ & $3.4580^{\mathrm{bc}} \pm 0.0139$ \\
\hline 3 & $0.6865^{\mathrm{a}} \pm 0.0061$ & $0.7213^{\mathrm{a}} \pm 0.0106$ & $3.7300^{\mathrm{ab}} \pm 0.0041$ & $3.6980^{\mathrm{a}} \pm 0.0331$ \\
\hline 6 & $0.6149^{\mathrm{b}} \pm 0.0075$ & $0.6423^{\mathrm{b}} \pm 0.0049$ & $3.4727^{\mathrm{c}} \pm 0.0095$ & $3.3819^{\mathrm{c}} \pm 0.0069$ \\
\hline Cont & $0.6128^{\mathrm{b}} \pm 0.0051$ & $0.6532^{\mathrm{b}} \pm 0.0154$ & $3.7946^{\mathrm{a}} \pm 0.0438$ & $3.471^{\mathrm{b}} \pm 0.0327$ \\
\hline F. Value & $71.41 * *$ & $23.94 * *$ & $56.56 * *$ & $61.83 * *$ \\
\hline L.S.D. & 0.0196 & 0.0326 & 0.0847 & 0.0785 \\
\hline
\end{tabular}

Table 4 show mean weights of cocoons and cocoon shells when larvae were fed on leaves treated with different concentrations of foliar fertilization after one day of treatment, mean weights of cocoons and cocoon shell decreased at $6 \%$ concentration compared with control, and the increase was non-significant at $1 \%$ and $3 \%$ concentrations compared with control.

On the other hand, Table 5. show highly significant increase in mean weights of cocoons and cocoon shells when larvae were fed on leaves treated with different concentrations of foliar fertilization after 2 weeks of treatment. The highest mean weights of cocoons and cocoon shells were achieved at $3 \%$ concentration, while no significant increase was achieved between control and other concentrations $(1 \%$ and $6 \%)$.

\subsection{Fecundity of female moths}

The fecundity of female moths of mulberry silkworm was affected by type of mulberry trees and different concentrations of foliar fertilization. The highest fecundity (525 eggs) were occurred in female moths produced from larvae fed on leaves of mulberry trees $M$. nigra compared with $M$. alba at $3 \%$ concentration after two weeks of treatment. Fecundity was also negatively affected by different concentrations of foliar fertilization when the larvae were fed on leaves treated after one day of treatment, Table 6. 
Table 4. Weights of cocoons, cocoon shell and shell ratio produced from larvae fed on mulberry leaves treated with foliar fertilization one day after treatment

\begin{tabular}{|c|c|c|c|c|c|c|}
\hline \multirow{2}{*}{ Conc (gm/liter) } & \multicolumn{2}{|c|}{ W. cocoons } & \multicolumn{2}{c|}{ W. cocoon shell } & \multicolumn{2}{c|}{ Shell ratio \% } \\
\cline { 2 - 7 } & $\boldsymbol{M}$ alba & $\boldsymbol{M}$. nigra & M. alba & M. nigra & M. alba & M. nigra \\
\hline 1 & $1.3233^{\mathrm{a}}$ & $1.1822^{\mathrm{a}}$ & $0.3238^{\mathrm{ab}}$ & $0.282^{\mathrm{a}}$ & 24.47 & 23.85 \\
\hline & \pm 0.0415 & \pm 0.0429 & \pm 0.0291 & \pm 0.0221 & & \\
\hline 3 & $1.3147^{\mathrm{a}}$ & $1.0829^{\mathrm{b}}$ & $0.2947^{\mathrm{b}}$ & $0.2743^{\mathrm{a}}$ & 22.41 & 25.33 \\
\hline & \pm 0.0412 & \pm 0.0149 & \pm 0.0067 & \pm 0.0126 & & \\
\hline 6 & $0.00^{\mathrm{b}}$ & $0.00^{\mathrm{c}}$ & $0.00^{\mathrm{c}}$ & $0.00^{\mathrm{b}}$ & 0 & 0 \\
\hline & \pm 0.00 & \pm 0.00 & \pm 0.00 & \pm 0.00 & & 26.99 \\
\hline Cont & $1.3617^{\mathrm{a}}$ & $1.0559^{\mathrm{b}}$ & $0.3590^{\mathrm{a}}$ & $0.2850^{\mathrm{a}}$ & 26.36 & \\
\hline F. Value & \pm 0.0148 & \pm 0.0286 & \pm 0.0163 & \pm 0.0059 & & \\
\hline L.S.D. & $977.6^{* *}$ & $858.1^{* *}$ & $187.7^{* *}$ & $230.6^{* *}$ & & \\
\hline
\end{tabular}

Table 5. Weights of cocoons, cocoon shell and shell ratio produced from larvae fed on mulberry leaves treated with foliar fertilization two weeks after treatment

\begin{tabular}{|c|c|c|c|c|c|c|}
\hline \multirow{2}{*}{ Conc $(\mathbf{g m} /$ liter $)$} & \multicolumn{2}{|c|}{ W. cocoons } & \multicolumn{2}{c|}{ W. cocoon shell } & \multicolumn{2}{c|}{ Shell ratio \% } \\
\cline { 2 - 7 } & M. alba & M. nigra & M. alba & M. nigra & M. alba & M. nigra \\
\hline 1 & $1.3655^{\mathrm{b}}$ & $1.2519^{\mathrm{a}}$ & $0.3376^{\mathrm{a}}$ & $0.2950^{\mathrm{a}}$ & 24.72 & 23.56 \\
\hline & \pm 0.0061 & \pm 0.0102 & \pm 0.0135 & \pm 0.0122 & & \\
\hline 3 & $1.4505^{\mathrm{a}}$ & $1.2800^{\mathrm{a}}$ & $0.3685^{\mathrm{a}}$ & $0.3126^{\mathrm{a}}$ & 25.41 & 24.42 \\
\hline & \pm 0.0132 & \pm 0.0273 & \pm 0.0077 & \pm 0.0093 & & \\
\hline 6 & $1.0814^{\mathrm{c}}$ & $1.0043^{\mathrm{b}}$ & $0.2380^{\mathrm{b}}$ & $0.2573^{\mathrm{b}}$ & 22.01 & 25.62 \\
\hline & \pm 0.0159 & \pm 0.0042 & \pm 0.0153 & \pm 0.0163 & & 26.99 \\
\hline Cont & $1.3617^{\mathrm{b}}$ & $1.0559^{\mathrm{b}}$ & $0.3590^{\mathrm{a}}$ & $0.2850^{\mathrm{ab}}$ & 26.36 & \\
\hline F. Value & \pm 0.0148 & \pm 0.0286 & \pm 0.0163 & \pm 0.0059 & & \\
\hline L.S.D. & $302.6^{* *}$ & $90.75^{* *}$ & $38.72^{* *}$ & $7.93^{* *}$ & & \\
\hline
\end{tabular}

Table 6. Fecundity of female moths produced from larvae which fed on leaves treated with foliar fertilization one day and two weeks after treatment

\begin{tabular}{|c|c|c|c|c|}
\hline \multirow{2}{*}{ Conc } & \multicolumn{2}{|c|}{ After one day } & \multicolumn{2}{c|}{ After 2 weeks } \\
\cline { 2 - 5 } & $\boldsymbol{M}$ alba & $\boldsymbol{M}$. nigra & $\boldsymbol{M}$. alba & M. nigra \\
\hline 1 & $400^{\mathrm{b}} \pm 8.6538$ & $467^{\mathrm{a}} \pm 6.6833$ & $451^{\mathrm{b}} \pm 1.6329$ & $507^{\mathrm{b}} \pm 3.2659$ \\
\hline 3 & $424^{\mathrm{a}} \pm 3.6817$ & $455^{\mathrm{b}} \pm 1.6329$ & $488^{\mathrm{a}} \pm 1.6329$ & $525^{\mathrm{a}} \pm 4.1096$ \\
\hline 6 & $0.00^{\mathrm{c}} \pm 0.00$ & $0.00^{\mathrm{c}} \pm 0.00$ & $383^{\mathrm{d}} \pm 2.0548$ & $505^{\mathrm{b}} \pm 2.4944$ \\
\hline Cont & $436^{\mathrm{a}} \pm 2.4494$ & $477^{\mathrm{a}} \pm 2.4494$ & $436^{\mathrm{c}} \pm 2.4494$ & $477^{\mathrm{c}} \pm 2.4494$ \\
\hline F. Value & $3758.2^{*} *$ & $8167.1 * *$ & $981.73^{*} *$ & $78.02^{* *}$ \\
\hline L.S.D. & 15.561 & 11.693 & 6.3151 & 10.099 \\
\hline
\end{tabular}




\section{Foliar Fertilization of Different Species of Mulberry Trees and Its Impact on Silkworm Bombyx mori Productivity from Cocoons and Eggs}

Balanced fertilization affects plants and fruit trees, which increases their production of the crop, whether it is in the leaves, the vegetative system, the fruits, or an increase in their nutritional value Carranca et al (2018). Also, yield of leaves and fruits of mulberry trees that are fertilized with a balanced fertilization are positively affected (Bose et al 2010, Ahmed et al 2018).

Venu et al (2019) sprayed leaf extracts of Panchagavya and vermiwash on mulberry trees. An increase of mulberry trees growth occurred and pest attack decreased,in addition to an increase in the nutritional value (Vijaya et al 2009, Bose et al 2011).

Baqual and Das (2006) inoculated mulberry trees with phosphate solubilizing microorganisms, nitrogen fixing bacteriaand arbuscular mycorrhiza, and analyzed the leaves of mulberry trees treated. They found higher contents of nitrogen, phosphorus and potassium. The treatments also affected the length of silk filament $(936.33 \mathrm{~m} / \mathrm{cocoon})$. Ghazy et al (2020) found that the number of shoots and length of shoots per tree and the number of leaves per shoot increased when mulberry trees were treated with vermicompost application.

The higher of nutritional value in mulberry leaves affects weights of mulberry silkworm larvae, cocoons, cocoon shell and length, weight and volume of silk filament, fecundity, hatchability of eggs, in addition to the larval duration and larval mortality (Vijaya et al (2009), Zannoonet al (2012), Chakraborty and Chakraborty (2016), Fathy et al (2016), Sudhakara et al (2017), Ahmed et al (2018), Ghazy et al (2018), Ghazy et al (2020)).

\section{Conclusion}

The productivity of mulberry silkworms from cocoons and the fertility of female moths can be improved by feeding the larvae on highly nutritious mulberry leaves with a balanced fertilization of NPK.

\section{References}

Abdelmegeed SM (2020) Biological and physiological effects on mulberry silkworm fed on mulberry leaves treated with yeast and soybean. Journal of Plant Protection and Pathology, Mansoura University 11, 349-351.

Abdelmegeed SM (2016) Influence of species and different varieties of mulberry trees on consumption and nutritional efficiency of the silkworm larvae Bombyx mori L. under temperate climate of Egypt. Journal of Plant Protection and Pathology, Mansoura University.7, 241-245.

Ahmed F, Abdul Kader M, Sultana R, Ahmed O, Begum SA, Iqbal MdT (2018) Combined application of foliar fertilizer with basal NPK enhances mulberry leaf yield and silkworm cocoon productivity in calcareous soil. Journal of South Pacific Agriculture 21, http://www.journalofsouthpacificagriculture.com/index.php/JOSPA

Asma CS, Akca Y, Genc C (2007) Effect of fertilizer rate on the growth, yield and fruit characteristics of dried apricot (cv. Hacihaliloglu). Asian Journal of Plant Sciences 6, 294-297.

Baqual MF; Das PK (2006) Influence of biofertilizers on macronutrient uptake by the

mulberry plant and its impact on silkworm bioassay. Caspian Journal of Environmental Science 4, 98-109.

Bose PC, Kar R, Bajp AAK (2010) Soil test based sulphur fertilization for targeted yields of mulberry. Journal of Crop and Weed 6, 2224.

Bose PC, Kar R, Majumder SK (2011) Effect of sulphur on yield, nutrient concentration and sulphur useefficiency of mulberry. Journal of Crop and Weed 7, 127-129.

Carranca C, Brunetto G, Tagliavini M (2018) Nitrogen nutrition of fruit trees to reconcile productivity and environmental concerns. Plants 7, 1-12 doi:10.3390/plants7010004 www.mdpi.com/journal/plants 
Chakraborty B, Chakraborty SK (2016) Influence of bio and organic nutrients oneconomic traits of mulberry silkworm Bombyx Mori L International Journal of Innovative Research in Science, Engineering and Technology 5, 21204-21209

DOI:10.15680/IJIRSET.2016.051205121204

Dhillon WS, Gill PPS, Singha NP (2011) Effect of nitrogen, phosphorus and potassium fertilization on growth, yield and quality of pomegranate 'Kandhari' DOI: 10.17660/ActaHortic.2011.890.45.

El-Khayat EF, Gaaboub IA, Omer REM, Ghazey UM, El-Shewy AM (2013) Impact of bio and inorganic fertilizer treatments on economic traits of mulberry silkworm (Bombyx mori L.). Academic Journal of Entomology 6, 01-06.

El-Shal MA, El-Araby SM, Ghoneim IM, Anter $\mathrm{H}$ (2003) Effects of biofertilization under varying npk levels on growth, yield and fruit quality of strawberry plants. Journal of Agriculture and Environmental Science Alexandria University 2, 106-129.

Fathy HM, Abd ElSalam AH, Ghazy UMM, Gad RS (2016) Impact of chemical fertilizer treatments on cocoon quality of silkworm Bombyx mori L. Journal of Plant Protection and Pathology, Mansoura University 7, 511 514.

Ghazy UM, FouadTA, AhmedGM(2018) Enhancement of mulberry silkworm bombyxmoril. characters using foliarfertilizers ascobein. Journal of Plant Protection and $\mathrm{Pa}$ thology, Mansoura University 9, 783-786.

Ghazy UM, FouadTA, Ahmed GM(2020) Improving productivity of mulberry trees and silkworm, Bombyx mori L., using vermicompost application. International Journal of Industrial Entomology 40, 41-50.

József R, Zoltán S, József N (2005) Effect of nutrient supply on fruit quality of apple (Malus domestica Borkh.) Journal of Central European Agriculture 6, 35-42.
Kamel HM (2014) The Effect of fertilized mulberry leaves with balanced NPK on the biological, quantitative and technological parameters of silkworm, Bombyx mori L. Middle East Journal of Agriculture Research 3, 988993.

Krishnaswami S (1983) Evolution of new bivoltine race for traditionally multivoltine areas of south India. Indian Silk 22, 3-11.

Łochyńska M (2018) Yield improvement of white mulberry in Poland by modern cultivation measures. International Journal of Research and Development 3, 103-109.

Mahmood R, Jan MT, Khan MI (2001) Effects of food from mulberry treated with urea " $n$ "on larval development and cocoon weight of silkworm Bombyx mori L. Journal of Research (Science), Bahauddinzakariya University, Multan, Pakistan 12, 123-129.

Pawan SJR, Satpa B, Surinder S, Mukesh K (2017) Effect of the time and severity of pruning on growth, yield and quality in mulberry (Morusalba L.). International Journal of Agriculture Sciences 9, 4861-4863.

Radi M, Mahrouz M, Jaouad A, Amiot MJ (2003) Influence of mineral fertilization (NPK) on the quality of apricot fruit (cv. $\mathrm{Ca}$ nino). The effect of the mode of nitrogen supply. Agronomie 23, 737-745. DOI: 10.1051/agro:2003052

Sakthivel N, Narendra KJB, Dhahira BN, Devamani M; Teotia RS (2019) Mulberry pests current status and management practices, Central Sericultural Research \& Training Institute Central Silk Board, Ministry of Textiles, Government of India. Https://Www.Researchgate.Net/Publication/334770499

Shinde KS, Avhad SB, Jamdar SV, Hiware CJ (2012) Impact of spacing, fertilizer on the productivity of mulberry (Morus alba L.) v1 variety. Science Bulletin 9, 276-280.

Sudhakara SN, Narayanaswamy TK, Narayanaswamy KC (2017) Role of integrated use of organic manures and inorganic fertilizers on mulberry and its impact on cocoon parameters 


\section{Foliar Fertilization of Different Species of Mulberry Trees and Its Impact on Silkworm Bombyx mori Productivity from Cocoons and Eggs}

of silkworm (Bombyx mori L.) International Journal of Current Microbiology and Applied Sciences 6, 3922-3927.

Sudhakar P, Hanumantharayappa SK, Swamy Gowda MR, Kumar JS, Sivaprasad JS (2018) Impact of micro irrigation methods on mulberry (Morus alba L.) leaf quality and production. International Journal of Pure \& Applied Bioscience 6, 332-339.

DOI: $\quad$ http://dx.doi.org/10.18782/23207051.6409

Sugiyama M, Takahashi M, Katsube T, Koyama A, Itamura H (2016) Effects of applied nitrogen amounts on the functional components of mulberry (Morus alba L.) leaves. Journal of Agricultural and Food Chemistry 64, 6923-6929.
Venu VS, Jothimani P, Kalpana PV, Devaghi P (2019) Effect of organic nutrition in enhancing mulberry and silkworm productivity. International Journal for Science and Advance Research in Technology 5, 595-600.

Vijaya D, Yeledhalli NA, Rav MV, Nagangoud A, Nagalikar VP (2009) Effect of fertilizer levels and foliar nutrition on M-5 mulberry leaf nutrient content, quality and cocoon production. Karnataka Journal of Agricultural Sciences 22,1006-1012.

Zannoon AA, Darweish AA, Khattab MM, Morssy GM (2012) Effect of adding some foliar fertilizers tomulberry leaves on some biological aspects and silk production of silkworm Bombyx mori L. International Journal of Product Development 17,211 - 221.

Doi:10.1021/acs.jafc.6b01922. 